NASA/TM-2005-213843

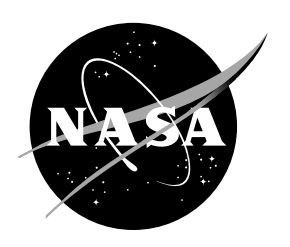

\title{
Polynomial Expressions for Estimating Elastic Constants From the Resonance of Circular Plates
}

Jonathan A. Salem

Glenn Research Center, Cleveland, Ohio

Abhishek Singh

Ohio Aerospace Institute, Brook Park, Ohio 
Since its founding, NASA has been dedicated to the advancement of aeronautics and space science. The NASA Scientific and Technical Information (STI) Program Office plays a key part in helping NASA maintain this important role.

The NASA STI Program Office is operated by Langley Research Center, the Lead Center for NASA's scientific and technical information. The NASA STI Program Office provides access to the NASA STI Database, the largest collection of aeronautical and space science STI in the world. The Program Office is also NASA's institutional mechanism for disseminating the results of its research and development activities. These results are published by NASA in the NASA STI Report Series, which includes the following report types:

- $\quad$ TECHNICAL PUBLICATION. Reports of completed research or a major significant phase of research that present the results of NASA programs and include extensive data or theoretical analysis. Includes compilations of significant scientific and technical data and information deemed to be of continuing reference value. NASA's counterpart of peerreviewed formal professional papers but has less stringent limitations on manuscript length and extent of graphic presentations.

- TECHNICAL MEMORANDUM. Scientific and technical findings that are preliminary or of specialized interest, e.g., quick release reports, working papers, and bibliographies that contain minimal annotation. Does not contain extensive analysis.

- CONTRACTOR REPORT. Scientific and technical findings by NASA-sponsored contractors and grantees.
- CONFERENCE PUBLICATION. Collected papers from scientific and technical conferences, symposia, seminars, or other meetings sponsored or cosponsored by NASA.

- SPECIAL PUBLICATION. Scientific, technical, or historical information from NASA programs, projects, and missions, often concerned with subjects having substantial public interest.

- TECHNICAL TRANSLATION. Englishlanguage translations of foreign scientific and technical material pertinent to NASA's mission.

Specialized services that complement the STI Program Office's diverse offerings include creating custom thesauri, building customized databases, organizing and publishing research results ... even providing videos.

For more information about the NASA STI Program Office, see the following:

- Access the NASA STI Program Home Page at http://www.sti.nasa.gov

- E-mail your question via the Internet to help@sti.nasa.gov

- Fax your question to the NASA Access Help Desk at 301-621-0134

- Telephone the NASA Access Help Desk at 301-621-0390

- Write to:

NASA Access Help Desk

NASA Center for AeroSpace Information 7121 Standard Drive

Hanover, MD 21076 
NASA/TM-2005-213843

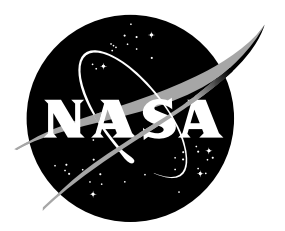

\section{Polynomial Expressions for Estimating Elastic Constants From the Resonance of Circular Plates}

Jonathan A. Salem

Glenn Research Center, Cleveland, Ohio

Abhishek Singh

Ohio Aerospace Institute, Brook Park, Ohio

National Aeronautics and

Space Administration

Glenn Research Center 


\section{Acknowledgments}

The authors thank the Summer High School Apprenticeship Research Program and the Low Emission Alternative Power program for funding this work.

This work was sponsored by the Low Emissions Alternative

Power Project of the Vehicle Systems Program at the NASA Glenn Research Center.

Available from

NASA Center for Aerospace Information 7121 Standard Drive

Hanover, MD 21076
National Technical Information Service 5285 Port Royal Road

Springfield, VA 22100

Available electronically at http:/ /gltrs.grc.nasa.gov 


\title{
Polynomial Expressions for Estimating Elastic Constants From the Resonance of Circular Plates
}

\author{
Jonathan A. Salem \\ National Aeronautics and Space Administration \\ Glenn Research Center \\ Cleveland, Ohio 44135 \\ Abhishek Singh \\ Ohio Aerospace Institute \\ Brook Park, Ohio 44142
}

\begin{abstract}
Two approaches were taken to make convenient spread sheet calculations of elastic constants from resonance data and the tables in ASTM C1259 and E1876: (1) polynomials were fit to the tables; (2) an automated spread sheet interpolation routine was generated. To compare the approaches, the resonant frequencies of circular plates made of glass, hardened maraging steel, alpha silicon carbide, silicon nitride, tungsten carbide, tape cast NiO-YSZ, and zinc selenide were measured. The elastic constants, as calculated via the polynomials and linear interpolation of the tabular data in ASTM C1259 and E1876, were found comparable for engineering purposes, with the differences typically being less than 0.5 percent. Calculation of additional $v$ values at $t / R$ between 0 and 0.2 would allow better curve fits. This is not necessary for common engineering purposes, however, it might benefit the testing of emerging thin structures such as fuel cell electrolytes, gas conversion membranes, and coatings when Poisson's ratio is less than 0.15 and high precision is needed.
\end{abstract}

\section{Introduction}

The elastic constants of isotopic materials can be measured by using a variety of static and dynamic techniques such as strain gages, impulse excitation, or resonant ultrasound spectroscopy, and a recent comparison of the techniques has been made (ref. 1). Dynamic techniques have the advantage of simple test specimen geometry, good precision, and applicability over a wide range of temperatures. One convenient method is the impulse excitation technique in which a test specimen such as a rectangular beam or circular plate is excited by a brief mechanical impulse with a tool (see fig. 1) and allowed to vibrate naturally. The specimen geometry and support and impact locations are chosen to induce flexural or torsional modes of vibration. The vibrations are detected with a non-contacting microphone or contact accelerometer, and are analyzed by a signal processor to determine the fundamental resonant frequency. The fundamental frequency is used with the specimen geometry and mass to estimate dynamic elastic properties such as Young's modulus, Poisson's ratio, and shear modulus.

This method is nondestructive, sensitive, requires relatively little material, and can be used to test specimens designed for other purposes such a uniaxial or biaxial flexural strength 
measurement (refs. 2 to 4). It also is useful for monitoring changes in newly developed materials that contain large amounts of porosity and undergo chemical changes such as reduction or oxidation during testing and use. Another advantage of the technique is the availability of American Society for Testing and Materials (ASTM) standards that give detailed guidance on the technique (refs. 5 and 6).

For a circular plate, the resultant first and second natural vibrations corresponding to torsion and flexure are measured and used to independently estimate Young's Modulus. The values are then used to calculate an average Young's modulus with the relation (ref. 5)

$$
E=\left(E_{1}+E_{2}\right) / 2
$$

where:

$$
E_{1}=\frac{37.6991 f_{1}^{2} D^{2} m\left(1-v^{2}\right)}{K_{1}^{2} t^{3}} \text { and } E_{2}=\frac{37.6991 f_{2}^{2} D^{2} m\left(1-v^{2}\right)}{K_{2}^{2} t^{3}}
$$

with $f_{1}$ and $f_{2}$ being the first and second natural frequencies, $D$ the disc diameter, $t$ the thickness, $m$ the mass, $v$ Poisson's ratio, and $K_{1}$ and $K_{2}$ the first and second natural geometric factors. The shear modulus, $G$, is calculated from the common relation

$$
G=\frac{E}{2(1+v)}
$$

Currently, the standards ASTM C1259 and E1876 (refs. 5 and 6) use linear interpolation of data compiled in tables to determine the constant $v$ as a function of $t / R$ and $f_{1} / f_{2}$ where $R$ is the disc radius. The constants $K_{1}$ and $K_{2}$ are then determined with linear interpolation as a function of $t / R$ and $v$. This is inconvenient as three manual interpolations are required per constant, and the accuracy is reduced because the functions are nonlinear and the interpolations of $K_{1}$ and $K_{2}$ depend on those of $v$. Although extremely accurate values of $E$ and $v$ are not needed for general engineering purposes, accurate constants are particularly useful in verification of test rigs and models. Further, rapid, convenient calculations are beneficial if elastic constants are used to nondestructively monitor material changes.

In order to allow accurate, convenient spread sheet calculations of elastic constants from plate data, two approaches were taken: (1) polynomials were fit to the data tables A1.1 to A1.5 of ASTM C1259 and E1876, which are identical and based on the data of Glandus and Martincek (refs. 7 and 8); and (2) an automated bilinear spread sheet interpolation routine was implemented (see the app.). The resultant polynomials exhibited residuals of less than 0.5 percent for $K_{l}$ and $K_{2}$, and less than 1.5 percent for $v$, and are sufficient for most engineering purposes.

Comparisons of calculations made with linear interpolation and the polynomials were made for glass, steel, silicon carbide, silicon nitride, tungsten carbide, tape cast NiO-YSZ and zinc selenide, and indicate similar results. 


\section{Polynomial Functions}

During fitting of the constants, an attempt was made to minimize the residuals while using a relatively simple polynomial function. This was possible for both $K_{1}$ and $K_{2}$, however reasonable fits could not easily be made for $v$. The most difficulty in fitting $v$ was encountered for values of $f_{2} / f_{1}=1.350$, for which $v$ varies by a factor of $\sim 6$ and changes from curvilinear behavior to very linear behavior at small $v$ as shown in figure 2. Thus three separate functions were generated to describe the range of $v$ given in table A1.1 of C1259. In addition, a wide range fit to the data of Glandus (ref. 7) that did not include values of $v$ for $f_{2} / f_{1}=1.350$ was generated. Other regions of the table that presented difficulty were additional columns containing several constant values of $v$, as with the $f_{2} / f_{1}=1.350$ data, and columns containing linearly increasing values of $v$ as a function of $t / R$. Such regions of constant $v$ or linearly changing $v$ did not follow a smooth trend as might be expected for a physical phenomenon. This may have resulted from the numerical accuracy available when Martincek did the calculations and the use of a nomogram to present the data, and the fact that many of the columns and rows in table A1.1 were generated by interpolation of the data of Glandus (ref. 7), rather than from direct calculation. Refinement of the calculations for $v$ as a function of $t / R$ and $f_{2} / f_{1}$ might allow better curve fits over a wider range.

An example of constant and linearly varying $v$ is shown in figure 2. Unfortunately, these complications tend to occur at small $t / R$ ratios, which are commonly used in the mechanical testing of structural ceramics such as membranes, fuel cell elements, and coatings that are being manufactured in very thin sections $(t / R<0.05)$ and are required to carry thermal and structural loads. Fortunately, the complications occur for $v$ values $(<0.15)$ not usually exhibited by ceramics (typical $v=0.16$ to 0.30 ) and the curves are relatively flat. For measurements of thin structures exhibiting low Poisson's ratio, improved values of $v$ between $t / R=0$ and 0.2 might be beneficial.

For $0 \leq t / R \leq 0.500, v$ can be described for $1.375 \leq f_{2} / f_{1} \leq 1.525,1.525 \leq f_{2} / f_{1} \leq 1.725$, and $1.725 \leq f_{2} / f_{1} \leq 1.900$ by the expression:

$$
\begin{aligned}
v=a+ & b\left(\frac{t}{R}\right)+c\left(\frac{f_{2}}{f_{1}}\right)^{-1}+d\left(\frac{t}{R}\right)^{2}+e\left(\frac{f_{2}}{f_{1}}\right)^{-2}+f\left(\frac{t}{R}\right)\left(\frac{f_{2}}{f_{1}}\right)^{-1}+g\left(\frac{t}{R}\right)^{3} \\
& +h\left(\frac{f_{2}}{f_{1}}\right)^{-3}+i\left(\frac{t}{R}\right)\left(\frac{f_{2}}{f_{1}}\right)^{-2}+j\left(\frac{t}{R}\right)^{2}\left(\frac{f_{2}}{f_{1}}\right)^{-1}
\end{aligned}
$$

where the constants $a$ through $j$ are given in table 1 . The fits are within 1 percent of the data in table A1.1 C1259. For the wider range of $0.00 \leq t / R \leq 0.500$, and $1.400 \leq f_{2} / f_{1} \leq 1.900, v$ can be estimated within 1.3 percent of the data of Glandus (ref. 7) by using the constants in the last row of table 1 with equation (4). The $v$ values corresponding to $f_{2} / f_{1}=1.350$ were not included in the fit because they decreased the quality of fit and are not commonly encountered in experimental measurements of ceramics. Examples of fits to the data are shown in figures 3 and 4.

For fitting of $K_{1}$ and $K_{2}$ data, minor difficulties occurred around some data points. Although Glandus added many intermediate data points to the range of $K_{l}$ and $K_{2}$ given by Martincek, he appears to have re-used Martincek's data directly without adding precision: the data in Glandus's 
tables are given to three places; however, many of the data points are identical to those of Martincek which were originally reported to two places. Evidently, Glandus simply added a third decimal (i.e., a zero) to Martincek's data rather than recalculating those points to a higher precision.

TABLE 1.-CONSTANTS FOR ESTIMATION OF $v$ FROM EQUATION (4)

\begin{tabular}{|c|c|c|c|c|}
\hline & \multicolumn{4}{|c|}{$f_{2} / f_{l}$ range } \\
\hline Coefficient & $1.375-1.525$ & $1.525-1.725$ & $1.725-1.900$ & $1.400-1.900$ \\
\hline$a$ & 0.7161 & -4.3343 & -8.0933 & -4.30526 \\
\hline$b$ & -0.6502 & 2.1017 & 3.4452 & 0.38999 \\
\hline$c$ & -4.1377 & 5.6718 & 12.2471 & 6.10124 \\
\hline$d$ & 1.0459 & 0.5107 & -2.2461 & 0.19582 \\
\hline$e$ & 4.2095 & -2.2025 & -6.1198 & -2.76353 \\
\hline$f$ & 0.6056 & -2.5965 & -3.2070 & -0.47553 \\
\hline$g$ & -0.5148 & -0.5109 & -0.0872 & -0.62008 \\
\hline$h$ & -1.1313 & 0.2792 & 1.0725 & 0.45518 \\
\hline$i$ & -0.1247 & 0.7924 & 0.7117 & 0.11816 \\
\hline$j$ & -0.3197 & 0.0283 & 1.4525 & 0.31933 \\
\hline
\end{tabular}

For $0 \leq t / R \leq 0.500$ and $0 \leq v \leq 0.500, K_{l}$ and $K_{2}$ can be described by the expression:

$$
K_{i}=\frac{\left(a+b\left(\frac{t}{R}\right)+c\left(\frac{t}{R}\right)^{2}+d v+e v^{2}+f v^{3}\right)}{\left(1+g\left(\frac{t}{R}\right)+h\left(\frac{t}{R}\right)^{2}+i v+j v^{2}\right)}
$$

where the constants $a$ through $j$ are given in table 2 . The fits are within 0.5 percent of the data in table A1.2 and A1.4 of C1259. For the narrow range of $0.100 \leq t / R \leq 0.200$ and $0.14 \leq v \leq 0.34$ given in tables A1.3 and A1.5, $K_{1}$ and $K_{2}$ can be described by the expression:

$$
\begin{gathered}
K_{i}=a+b\left(\frac{t}{R}\right)+c v+d\left(\frac{t}{R}\right)^{2}+e v^{2}+f\left(\frac{t}{R}\right) v+g\left(\frac{t}{R}\right)^{3} \\
+h v^{3}+i\left(\frac{t}{R}\right) v^{2}+j\left(\frac{t}{R}\right)^{2} v
\end{gathered}
$$

The fits are within 0.1 percent of the data. Examples of fits to the data are shown in figures 5 to 8 . 
TABLE 2.-CONSTANTS FOR EQUATIONS (5) AND (6)

\begin{tabular}{|c|c|c|c|c|}
\hline & $0 \leq t / R \leq 0.500$ and $0 \leq v \leq 0.500$ & \multicolumn{2}{c|}{$0.100 \leq t / R \leq 0.200$ and $0.14 \leq v \leq 0.34$} \\
\hline Coefficient & $K_{l}$ & $K_{2}$ & $K_{I}$ & $K_{2}$ \\
\hline$a$ & 6.1528 & 8.2584 & 6.2305 & 8.3901 \\
\hline$b$ & 0.5085 & -2.3794 & -1.7997 & -2.9434 \\
\hline$c$ & 0.8825 & 6.6164 & -2.4825 & 2.0928 \\
\hline$d$ & -3.9037 & 2.3540 & 3.6354 & 5.0895 \\
\hline$e$ & -5.4739 & -9.1109 & -0.3022 & 1.9810 \\
\hline$f$ & 3.9297 & -0.9923 & 3.6488 & 2.7693 \\
\hline$g$ & 0.1364 & -0.2142 & -9.3417 & -18.3125 \\
\hline$h$ & 0.9120 & 1.7467 & -2.2626 & -3.0307 \\
\hline$i$ & -0.3628 & -0.0475 & -3.3588 & -3.1336 \\
\hline$j$ & -0.3612 & -0.9262 & -10.7968 & -15.1250 \\
\hline
\end{tabular}

\section{Experimental Results}

In order to directly compare test results using linear interpolation and the polynomials, circular plates machined in accordance with the procedures of ASTM C1161 and C1499 (refs. 1 and 2) were tested. The dimensions and mass of all the test specimens were measured with a resolution of $0.001 \mathrm{~mm}$ and $0.0001 \mathrm{~g}$, respectively. The plates were typically $50.1 \mathrm{~mm}$ in diameter and ranged in thickness from 1.54 to $4.53 \mathrm{~mm}(t / R=0.06$ to 0.18$)$, and were intended for strength testing. The materials included glass, hardened maraging steel, alpha silicon carbide, silicon nitride, tungsten carbide, NiO-Yttria-stabilized zirconia (YSZ), and zinc selenide. The $75 \mathrm{~mol} \% \mathrm{NiO}-\mathrm{YSZ}$ was an unreduced anode material with $\sim 32$ percent porosity. It was manufactured by tape casting and sintered at $1200{ }^{\circ} \mathrm{C}$ for 2 hours as part of a fuel cell program being conducted at NASA Glenn Research Center (ref. 9). The zinc selenide was optical grade material made by chemical vapor deposition and intended for use on the International Space Station (ref. 10).

The test specimens were supported on the torsional or flexural nodal lines, as necessary, with foam rubber supports as shown in figure 1 and lightly impacted with a steel tipped hammer. The results are summarized in tables 3 and 4, and indicate that the differences in Poisson's ratio and Young's modulus as estimated from interpolation and the polynomials are usually less than 0.5 percent.

\section{Conclusion}

Polynomial fits and linear interpolation of the data tables of ASTM C1259 and E1876 produce comparable estimates of Poisson's ratio and Young's modulus for engineering purposes. For glass, hardened maraging steel, alpha silicon carbide, silicon nitride, tungsten carbide, NiOYSZ, and zinc selenide the differences as calculated from polynomials and interpolation were typically less than 0.5 percent. Calculation of additional $v$ values at $t / R$ between 0 and 0.2 would allow better curve fits and might benefit the testing of emerging thin structures such as fuel cell electrolytes, gas conversion membranes, and coatings when Poisson's ratio is less than 0.15 and high precision is needed. However, the current values are sufficient for common engineering purposes. 



\section{Appendix}

The following Microsoft ${ }^{\circledR}$ Excel macro ${ }^{1}$ was used to linearly interpolate values of $v, K_{l}$, and $K_{2}$. The interpolated values were used with the physical data in tables 3 and 4 to estimate $E_{l}$ and $E_{2}$ which were than averaged to find the Dynamic Young's Modulus $(E)$.

\section{'USER DEFINED FUNCTION}

'XYinterpolate

'Interpolates values from a named 2D table for row (x) and column(y) variables.

'The named table should include the row and column variables.

'Cell $(1,1)$ should not contain a numeric value or formula.

'Row variables should increase to the right. Column variables should increase downwards.

Static Function XYinterpolate(xyarray As Variant, x, y As Single) As Single

Dim $\mathrm{n} 1, \mathrm{~m} 1$ as integer

Dim x1, x2, y1, y2, Ry1x1, Ry1x2, Ry1x1x2, Ry2x1, Ry2x2, Ry2x1x2 As Single

$\mathrm{x} 1=$ Application.HLookup(x, xyarray, 1$)$

$\mathrm{n} 1=$ Application.Match $(\mathrm{x} 1$, xyarray.Rows $(1), 0)$

$\mathrm{x} 2=$ xyarray.Cells $(1, \mathrm{n} 1+1)$.Value

y1 = Application.VLookup(y, xyarray, 1)

$\mathrm{m} 1=$ Application.Match $(\mathrm{y} 1$, xyarray.Columns $(1), 0)$

y2 = xyarray.Cells $(\mathrm{m} 1+1,1)$.Value

Ry1x1 = xyarray.Cells $(\mathrm{m} 1, \mathrm{n} 1)$

Ry1x2 = xyarray.Cells $(\mathrm{m} 1, \mathrm{n} 1+1)$

Ry1x1x2 $=(x-x 1) /(x 2-x 1) *(R y 1 x 2-R y 1 x 1)+R y 1 x 1$

Ry $2 \times 1=$ xyarray.Cells $(\mathrm{m} 1+1, \mathrm{n} 1)$

Ry2x2 = xyarray.Cells $(\mathrm{m} 1+1, \mathrm{n} 1+1)$

Ry2x1x2 $=(x-x 1) /(x 2-x 1) *(\operatorname{Ry} 2 x 2-R y 2 x 1)+R y 2 x 1$

XYinterpolate $=(\mathrm{y}-\mathrm{y} 1) /(\mathrm{y} 2-\mathrm{y} 1)^{*}(\mathrm{Ry} 2 \mathrm{x} 1 \mathrm{x} 2-\mathrm{Ry} 1 \mathrm{x} 1 \mathrm{x} 2)+\mathrm{Ry} 1 \mathrm{x} 1 \mathrm{x} 2$

End Function

${ }^{1}$ This macro was courtesy of Dennis Kirk Engineering, denniskb@ozemail.com.au. 


\section{References}

1. M. Radovic, E. Lara-Curzio, and L. Riester, "Comparison of different experimental techniques for determination of elastic properties of solids," Materials Science and Engineering, A368, 2004, pp. 56-70.

2. ASTM C 1161-90, "Standard Test Method for Flexural Strength of Advanced Ceramics at Ambient Temperature," American Society for Testing and Materials Annual Book of Standards, vol. 15.01, 333-339, 1990.

3. ASTM C 1499-01 "Determination of Monotonic Biaxial Flexural Strength Advanced Ceramics," American Society for Testing and Materials Annual Book of ASTM Standards, vol. 15.01, 779-788, 2001.

4. J.A. Salem and L.M. Powers, "Guidelines for the Testing of Plates," pp. 357-364 in Proceedings of the 27th International Cocoa Beach Conference on Advanced Ceramics and Composites: B, Ceramic Engineering and Science Proceedings, vol. 24, no. 4, Waltraud M. Kriven and H.T. Lin, editors (January, 2003).

5. ASTM C 1259-01, "Standard Test Method for Dynamic Young's Modulus, Shear Modulus, and Poisson's Ratio for Advanced Ceramics by Impulse Excitation of Vibration," American Society for Testing and Materials Annual Book of Standards, vol. $15.01,2004$.

6. ASTM E 1876-01, "Standard Test Method for Dynamic Young's Modulus, Shear Modulus, and Poisson's Ratio by Impulse Excitation of Vibration," American Society for Testing and Materials Annual Book of Standards, vol. 03.01, 2003.

7. J.C. Glandus, "Rupture Fragile et Résistance aux Choes Thermiques de Céramiques a Usages Mecaniques," Thesis, University of Limoges, France, 1981.

8. G. Martincek, "The Determination of Poisson's Ratio and the Dynamic Modulus of Elasticity from the Frequencies of Natural Vibration in Thick Circular Plates," Journal of Sound Vibration, vol. 2, no. 2, 1965, pp. 116-127.

9. L.M. Anderson and A.K. Misra, "Solid Oxide Fuel Cell Materials Challenges for Aircraft," NATO AGARD Symposium on Novel and Emerging Vehicle Technology Concepts, Brussels, Belgium, April 7011, 2003.

10. J.A. Salem, "Estimation of ZnSe Crack Growth Properties for Design of the FEANICS (Flow Enclosure Accommodating Novel Investigations in Combustion of Solids) Windows," NASA TM 213359, 2005. 


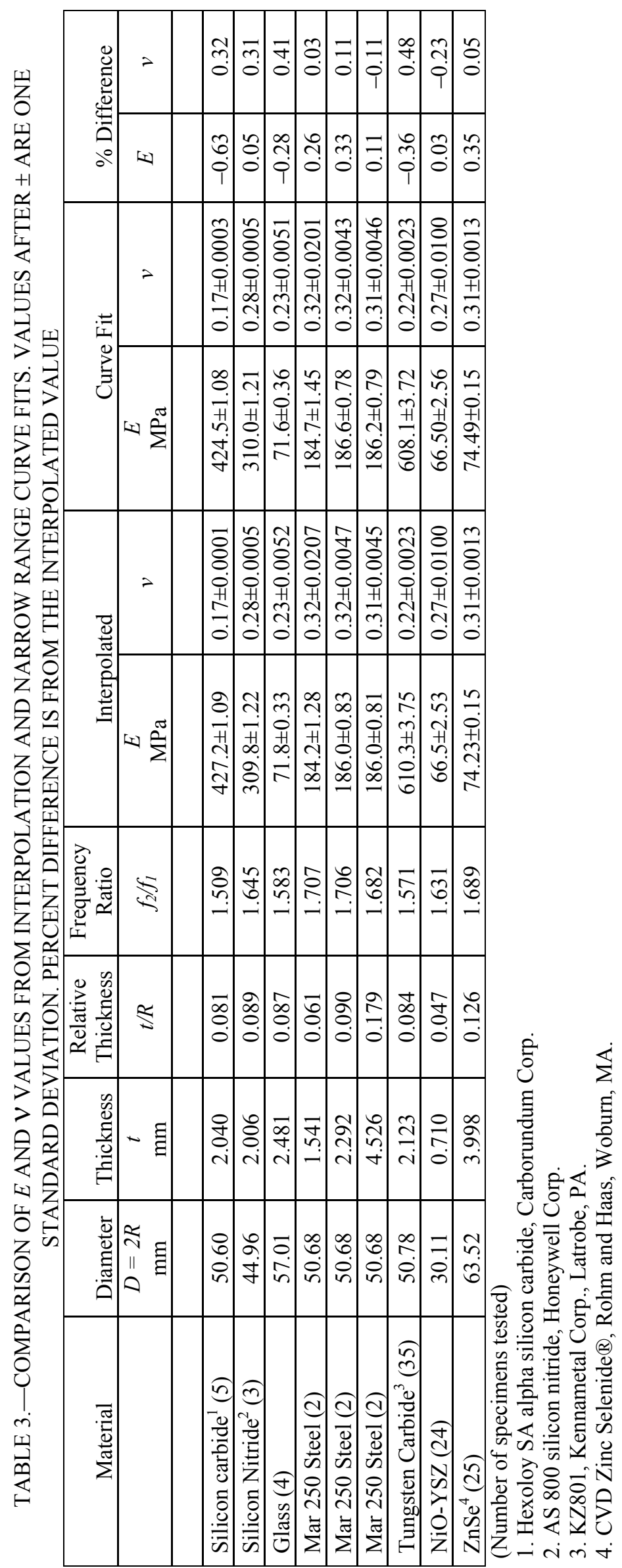




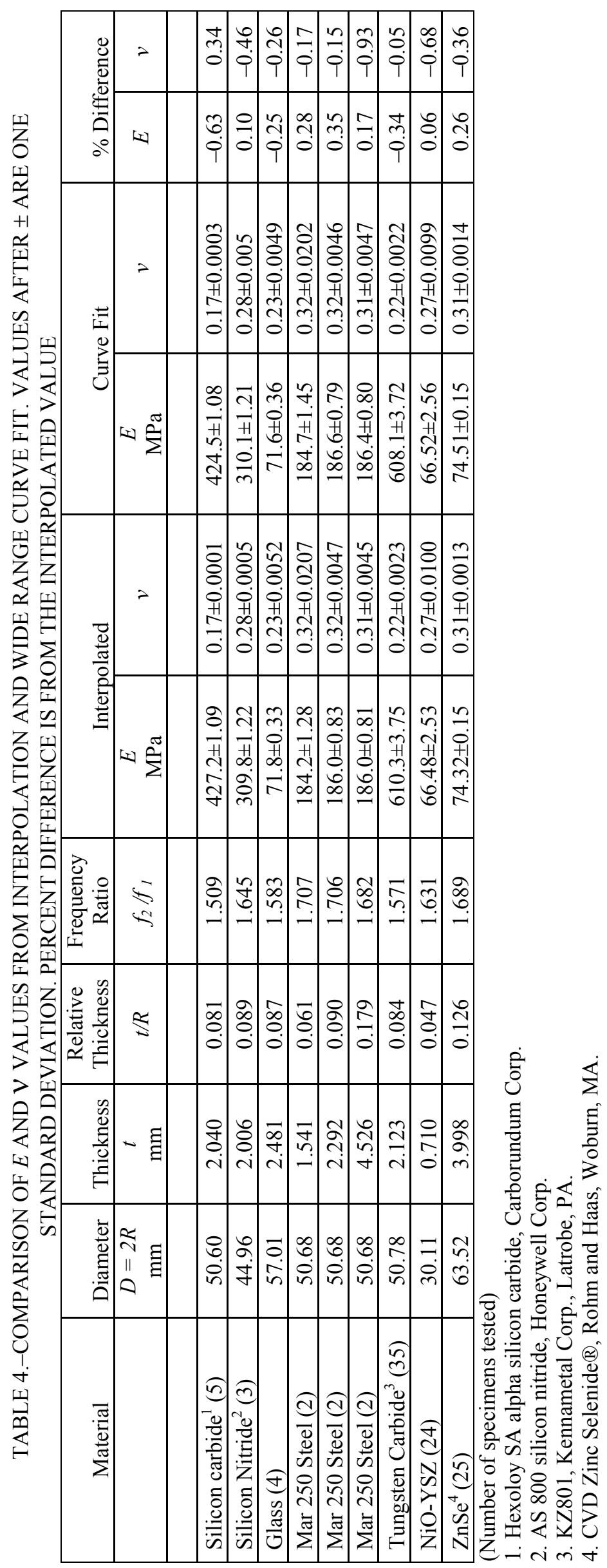



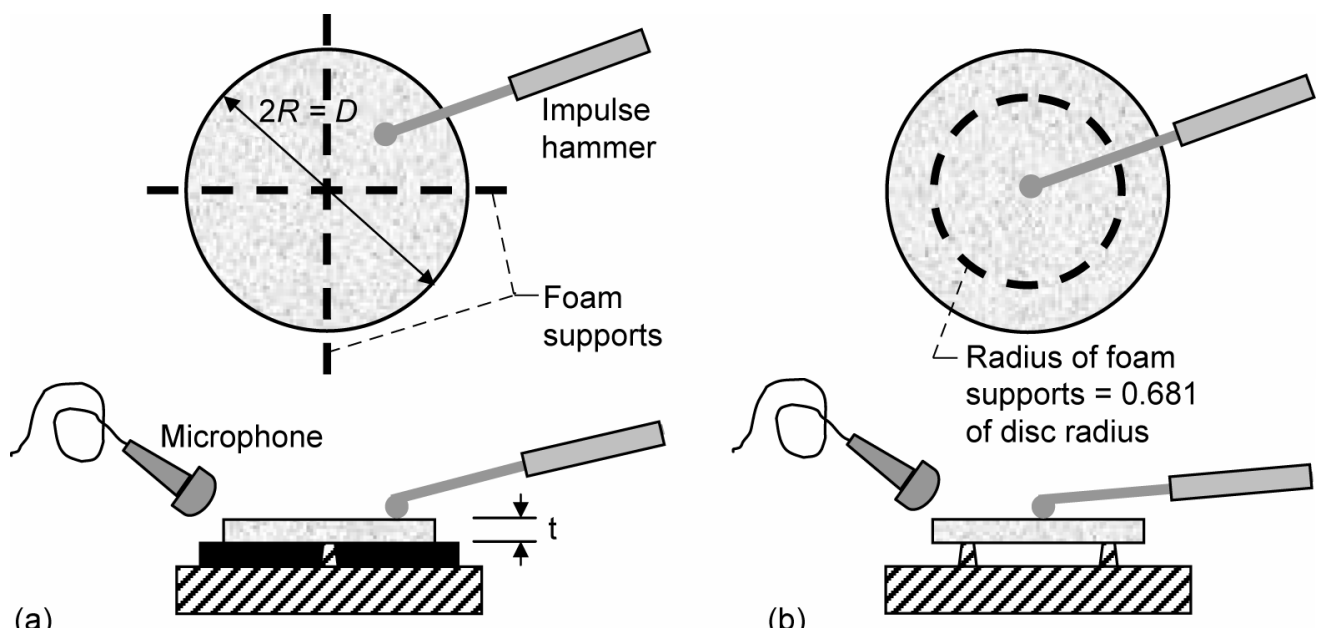

Figure 1.-Schematic of support setup for Impulse Excitation Technique: (a) torsional mode of vibration and (b) flexural mode of vibration. 


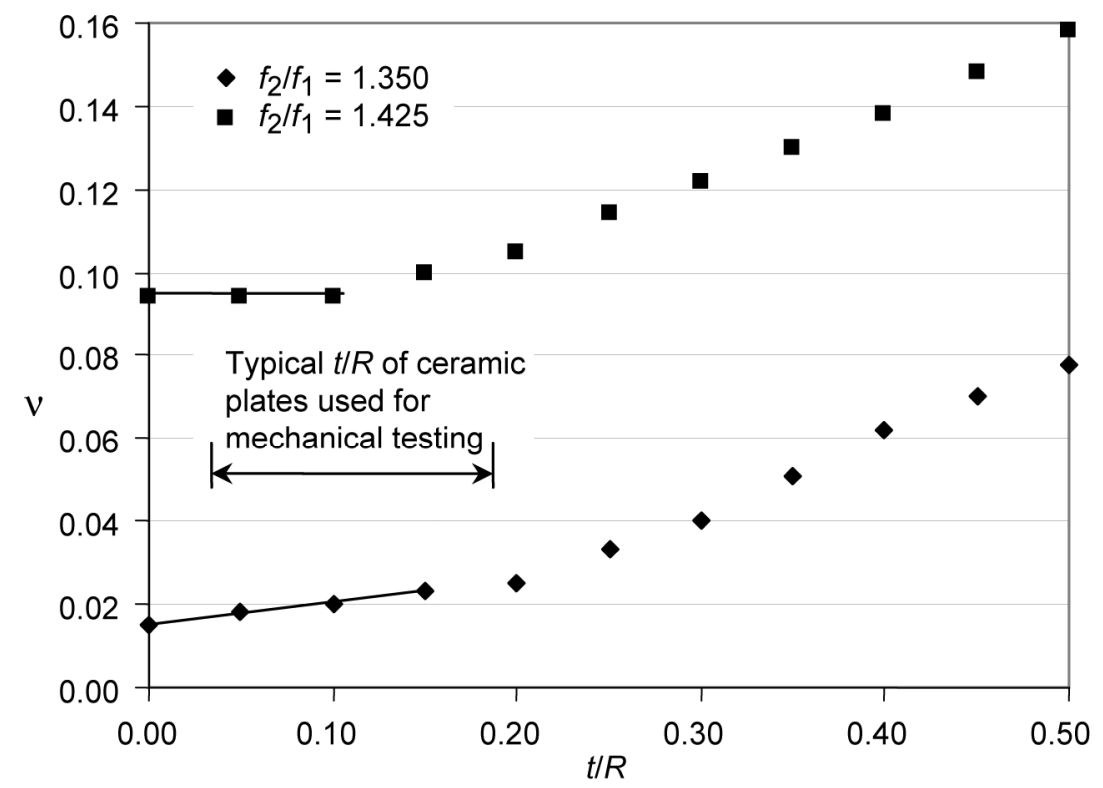

Figure 2. $-V$ as a function of $t / R$ for regions exhibiting linear variation or no variation of $V$ with $t / R$. The data is from table A1.1 of ASTM C1259 (ref. 4).

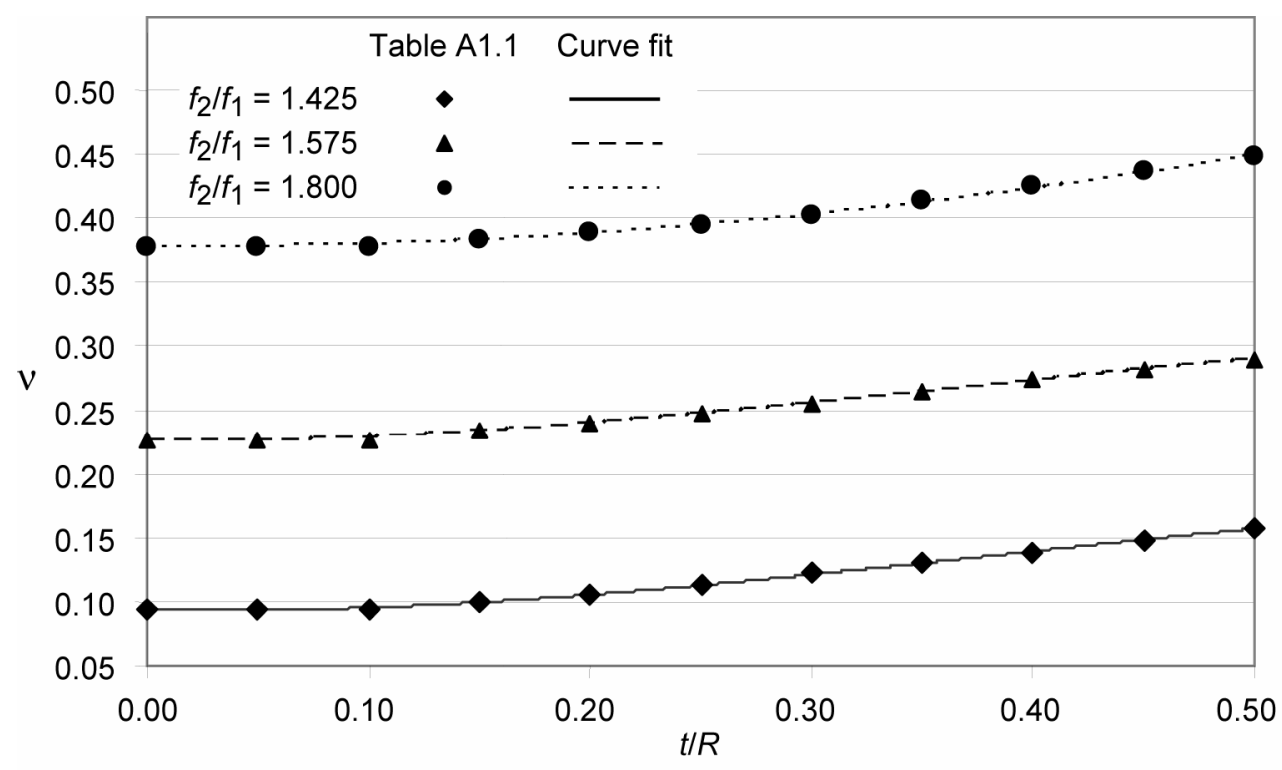

Figure 3. $-V$ as a function $t / R$ for various $f_{2} / f_{1}$. Solid lines are equation 4 , solid symbols are data points from table A1.1 of ASTM C1259 (ref. 4) and references 6 and 7. 


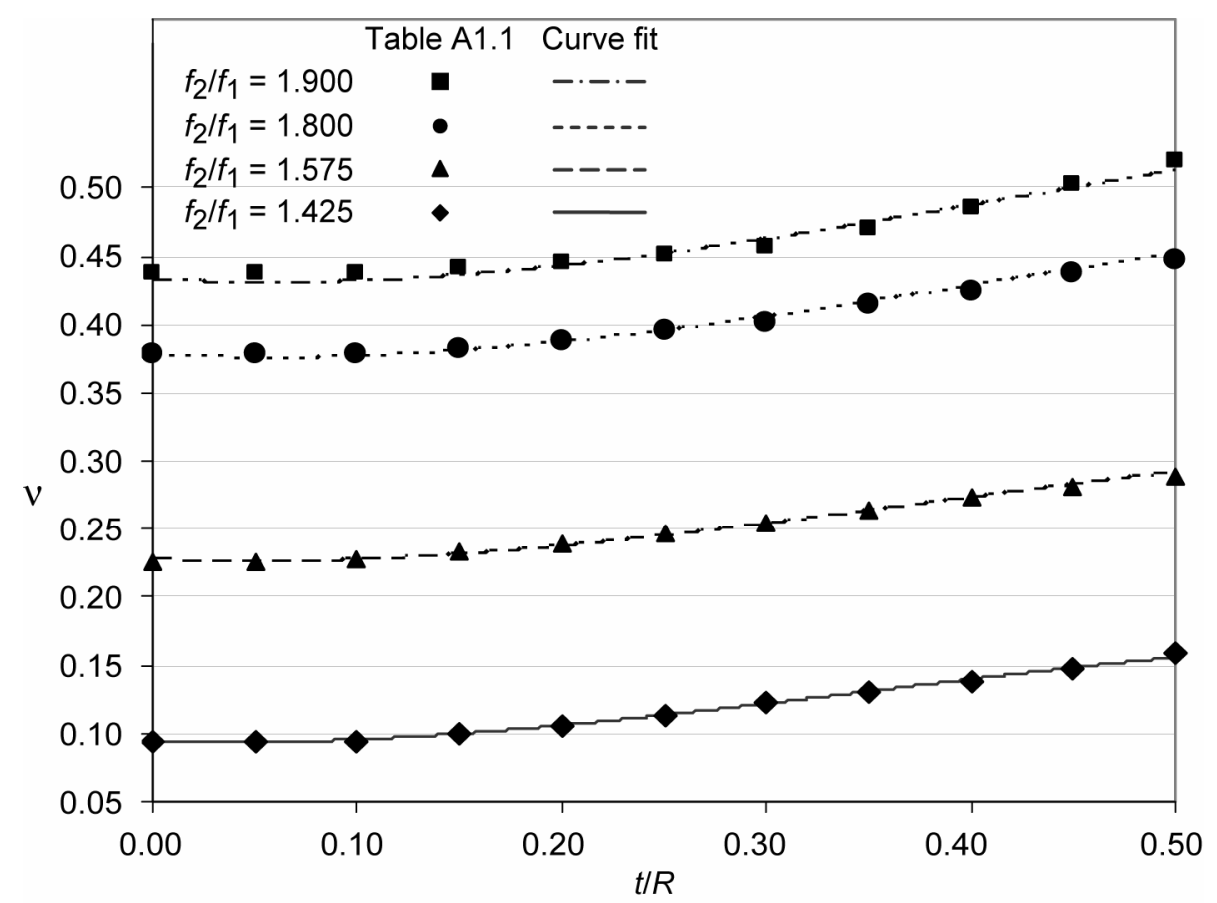

Figure 4. $-V$ as a function $t / R$ for various $f_{2} / f_{1}$. Solid lines are equation (4) wide range fit, solid symbols are data points from table A1.1 of ASTM C1259 (ref. 4) and references 6 and 7 .

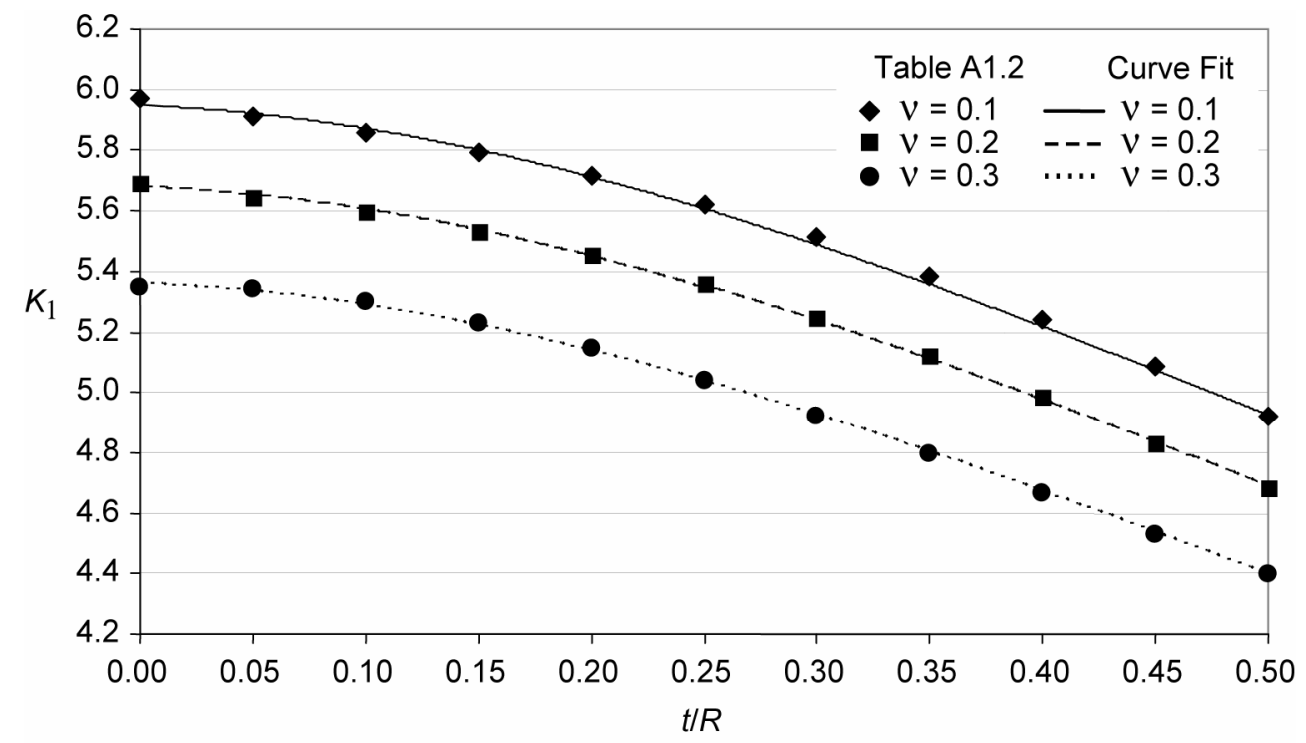

Figure 5.- $K_{1}$ as a function $t / R$ for various $v$. Solid lines are equation (5), solid symbols are data points from table A1.2 of ASTM C1259 (ref. 4) and references 6 and 7. 


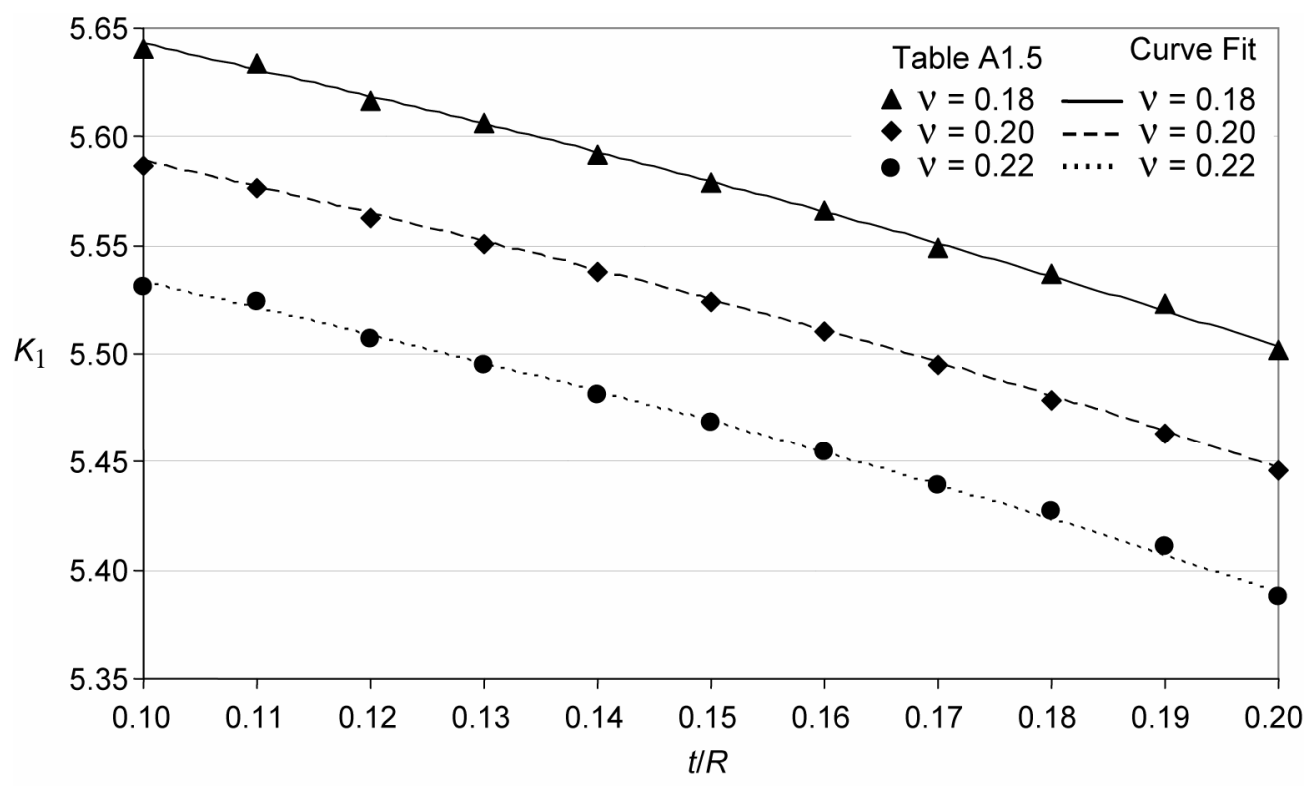

Figure 6. $-K_{1}$ as a function $t / R$ for various $v$. Solid lines are equation (6), solid symbols are data points from table A1.3 of ASTM C1259 (ref. 4) and references 6 and 7.

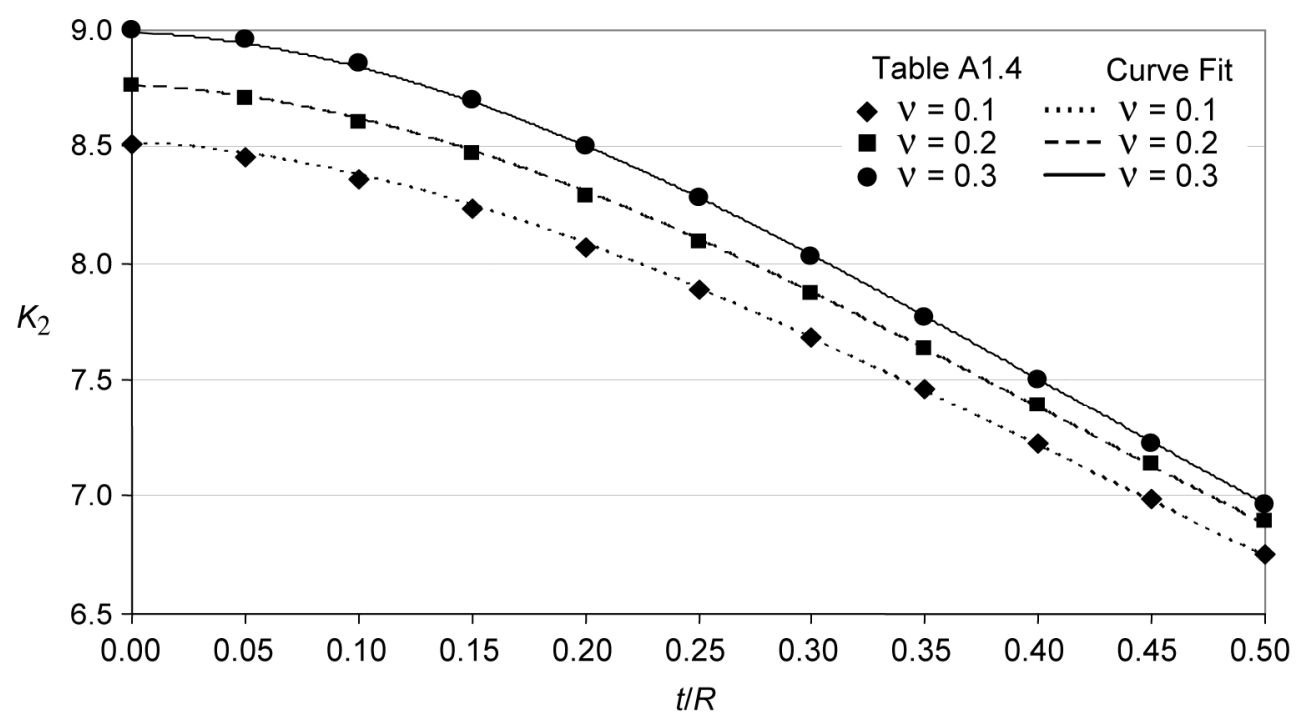

Figure $7 .-K_{2}$ as a function $t / R$ for various $V$. Solid lines are equation (5), solid symbols are data points from table A1.4 of ASTM C1259 (ref. 4) and references 6 and 7. 


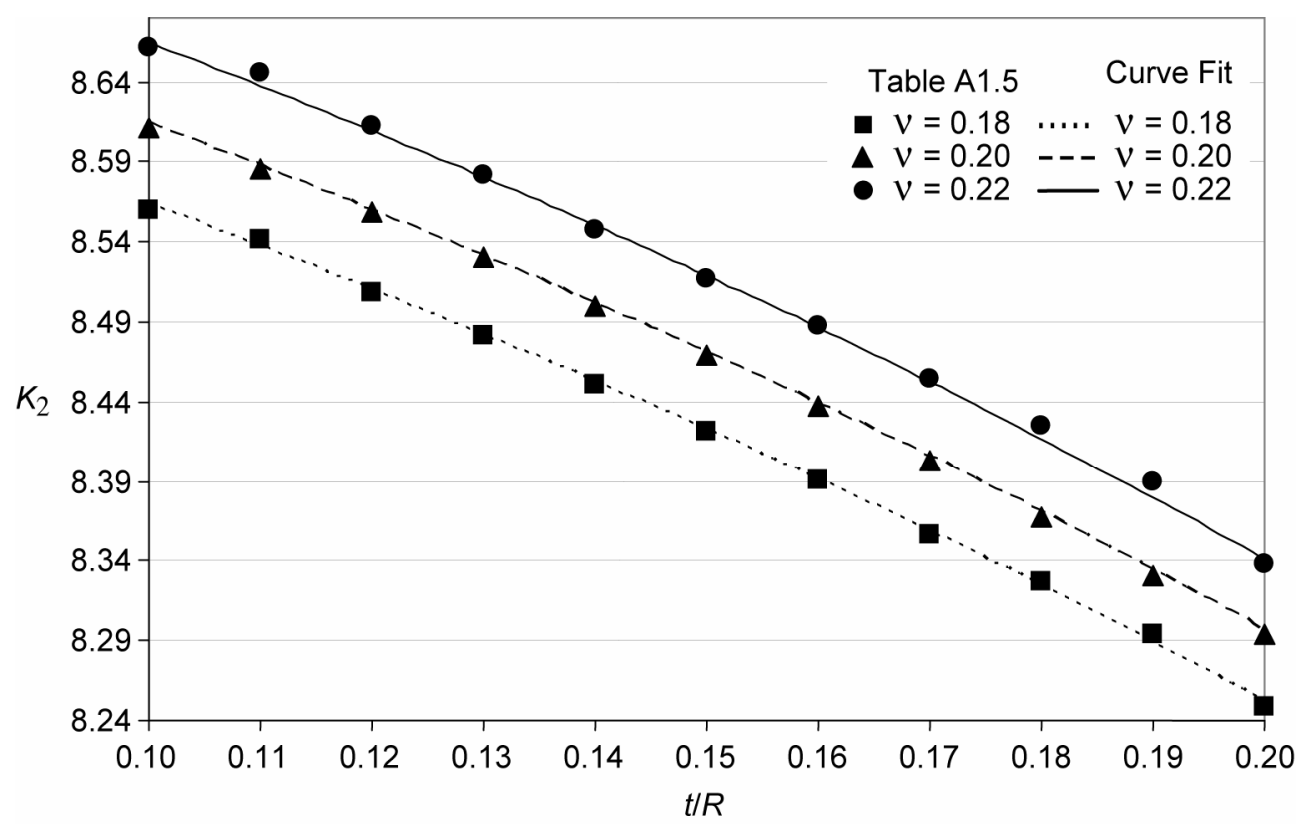

Figure 8. $-K_{2}$ as a function $t / R$ for various $v$. Solid lines are equation (6), solid symbols are data points from table A1.5 of ASTM C1259 (ref. 4) and references 6 and 7. 
Public reporting burden for this collection of information is estimated to average 1 hour per response, including the time for reviewing instructions, searching existing data sources, gathering and maintaining the data needed, and completing and reviewing the collection of information. Send comments regarding this burden estimate or any other aspect of this collection of information, including suggestions for reducing this burden, to Washington Headquarters Services, Directorate for Information Operations and Reports, 1215 Jefferson Davis Highway, Suite 1204, Arlington, VA 22202-4302, and to the Office of Management and Budget, Paperwork Reduction Project (0704-0188), Washington, DC 20503.

\begin{tabular}{|l|l|l}
\hline 1. AGENCY USE ONLY (Leave blank) & $\begin{array}{c}\text { 2. REPORT DATE } \\
\text { August } 2005\end{array}$ & $\begin{array}{c}\text { 3. REPORT TYPE AND DATES COVERED } \\
\text { Technical Memorandum }\end{array}$
\end{tabular}

4. TITLE AND SUBTITLE

5. FUNDING NUMBERS

Polynomial Expressions for Estimating Elastic Constants From the Resonance of Circular Plates

6. AUTHOR(S)

Jonathan A. Salem and Abhishek Singh

7. PERFORMING ORGANIZATION NAME(S) AND ADDRESS(ES)

National Aeronautics and Space Administration

John H. Glenn Research Center at Lewis Field

Cleveland, Ohio 44135-3191

WBS-22-066-30-03

9. SPONSORING/MONITORING AGENCY NAME(S) AND ADDRESS(ES)

National Aeronautics and Space Administration

Washington, DC 20546-0001

8. PERFORMING ORGANIZATION REPORT NUMBER

E-15217

10. SPONSORING/MONITORING AGENCY REPORT NUMBER

NASA TM-2005-213843

\section{SUPPLEMENTARY NOTES}

Jonathan A. Salem, NASA Glenn Research Center; and Abhishek Singh, Summer Intern, Ohio Aerospace Institute, 22800 Cedar Point Road, Brook Park, Ohio 44142. Responsible person, Jonathan A. Salem, organization code RSL, 216-433-3313.

12a. DISTRIBUTION/AVAILABILITY STATEMENT 12b. DISTRIBUTION CODE

Unclassified - Unlimited

Subject Category: 27

Available electronically at http://gltrs.grc.nasa.gov

This publication is available from the NASA Center for AeroSpace Information, 301-621-0390.

13. ABSTRACT (Maximum 200 words)

Two approaches were taken to make convenient spread sheet calculations of elastic constants from resonance data and the tables in ASTM C1259 and E1876: polynomials were fit to the tables; and an automated spread sheet interpolation routine was generated. To compare the approaches, the resonant frequencies of circular plates made of glass, hardened maraging steel, alpha silicon carbide, silicon nitride, tungsten carbide, tape cast NiO-YSZ, and zinc selenide were measured. The elastic constants, as calculated via the polynomials and linear interpolation of the tabular data in ASTM C1259 and E1876, were found comparable for engineering purposes, with the differences typically being less than 0.5 percent. Calculation of additional $v$ values at $\mathrm{t} / \mathrm{R}$ between 0 and 0.2 would allow better curve fits. This is not necessary for common engineering purposes, however, it might benefit the testing of emerging thin structures such as fuel cell electrolytes, gas conversion membranes, and coatings when Poisson's ratio is less than 0.15 and high precision is needed.

14. SUBJECT TERMS 15. NUMBER OF PAGES

Dynamic modulus of elasticity; Resonance; Poisson's ratio; Ceramics; Metals; Standards; Circular plates; Interpolation; Resonant vibration

\begin{tabular}{|c|c|}
\hline $\begin{array}{c}\text { 17. SECURITY CLASSIFICATION } \\
\text { OF REPORT } \\
\text { Unclassified }\end{array}$ & $\begin{array}{c}\text { 18. SECURITY CLASSIFICATION } \\
\text { OF THIS PAGE } \\
\text { Unclassified }\end{array}$ \\
\hline
\end{tabular}

19. SECURITY CLASSIFICATION OF ABSTRACT

Unclassified
20

16. PRICE CODE 

